\title{
THE LEGAL IMPLICATION OF COMPULSORY LICENCE PHARMACEUTICAL PRODUCTS IN THE TRIPS AGREEMENT TO THE PROTECTION OF THE RIGHT TO HEALTH IN DEVELOPING COUNTRIES ${ }^{\Omega}$
}

\author{
Sri Wartini \\ Faculty of Law, Universitas Islam Indonesia - Indonesia \\ E-mail: sri.wartini@uii.ac.id
}

\begin{abstract}
Compulsory license of pharmaceutical products in the Trade Related Aspects of Intellectual Property Rights (TRIPs) Agreement attempts to balance the interest of patent holders and The right to health. The access of medicines in developing countries for the epidemic diseases, such as, HIVIAIDS medicine is crucial to protect The right to health. The objective of the research is to analyze comprehensively the legal implication of compulsory license for the pharmaceutical product to the protection of The right to health in developing countries. It is a normative juridical research by applying conceptual and comparative approaches. The results of the research shows that: first, the implementation of compulsory licence is in accordance with the international human right law: second, the legal implication of the compulsory license causes the adoption of policy and regulations regarding the protection of the right to health in developing countries, such as Indonesia, Malaysia, Brazil, India and South Africa.
\end{abstract}

Key words : Compulsory license, pharmaceutical products, legal implication and The right to health

\begin{abstract}
Abstrak
Lisensi wajib produk farmasi dalam perjanjian perdagangan yang terkait dengan HKI berusaha menyeimbangkan kepentingan pemegang hak paten dan perlindungan hak kesehatan di negara berkembang. Akses terhadap obat di negara berkembang yang mengalami wabah penyakit seperti HIV/ AIDs sangat penting untuk melindungi hak kesehatan di negara berkembang. Tujuan penelitian ini untuk menganalisa secara komprehensif implikasi hukum lisensi wajib terhadap perlindungan hak kesehatan di negara berkembang. Penelitian ini merupakan penelitian yuridis normatif dengan pendekatan konseptual dan komparatif, serta dianalisa secara deskriptif kualitatif dan disajikan secara deskriftif. Adapun hasil penelitian ini ialah: pertama, implementasi lisensi wajib dalam Perjanjian TRIPs di negara berkembang terhadap produk parmasi sesuai dengan ketentuan hukum hak asasi manusia internasional; kedua implikasi hukum lisensi wajib terhadap produk parmasi di negara berkembang menyebabkan obat-obat yang penting untuk penyembuhan HIV/AIDs mudah diakses dan harganya terjangkau, seperti misalnya di Indonesia, Malaysia, Brasil, India and Africa Selatan untuk melindungi hak atas kesehatan.
\end{abstract}

Kata kunci: hak kesehatan. implikasi hukum, lisensi wajib, dan produk pharmacy,

Introduction

Developing countries are suffering from expensive essential medicines to secure deadly diseases such as HIV/AIDs. For example, World Health Organization (WHO) reports ${ }^{1}$ show that

$\Omega$ The article is part of individual research, funded by $\mathrm{Fa}$ culty of Law Universitas Islam Indonesia by Decree Number 1/Kaprodi/70/Div.URT/TU/H/6/2017.

Chuan-Feng Wu, "Transnational Pharmaceutical Corporations' Legal and Moral Human Rights Responsibilities in Relation to Access to Medicines", Asian Journal of infectious diseases kill over 14 million people per year, $90 \%$ of whom live in a developing or newly industrialized society. ${ }^{2}$ Among them, approximately three million people die annually from HIV/AIDS, two million from tuberculosis, and one million from malaria. ${ }^{3}$

WTO \& International Health Law \& Policy, Vol. 7, 2012, p. 78.

Ibid.

Ibid 
There are many states become the parties of international human rights instruments which recognized the rights to health, as well as the parties of Trade Related Aspect of Intellectual Property Rights Agreement (hereinafter TRIPs Agreement). One of the patented medicines is Antiretroviral which is able to secure the lethal disease, such as HIV/AIDS. ${ }^{4}$ From the perspective of intellectual property right Law, an expensive price of patented medicine, such as "antiretroviral' is reasonable since the pharmaceutical industries have already invested a huge capital and technology to create the medicine. In order to protect their products, they patented their products so they have the exclusive right ${ }^{5}$ to determine the price and prohibit the other parties to produce without their consent.

On the other hand, patients in developing countries really deserve the medicine, but they do not have capability to purchase the medicine. Consequently, the government of the developing countries failed to perform the obligation to protect, to fulfil and to promote the right to health which is stipulated in the International Coveant on Social, Economic and Cultural rights (hereinafter ICESCR). ${ }^{6}$ However, the World Trade organization (hereinafter WTO) as an international trade organisation states that it is necessary to regulate the access of the essential medicine, so that it can be purchased by the patients in developing countries including Indonesia by exercising compulsory license. The paper urgently attempts to examine the relationship between compulsory

Senai W. Andemariam, "The Cleft-Stick between AntiRetroviral Drug Patents and HIV/AIDS Victims: An InDepth Analysis of the WTO's Trips Article 31 Bis Amendment Proposal of 6 December 2005", Intellectual Property Quarterly, Vol. 4, 2007, p. 415.

5 Lilian Martins, "The Right to Health Versus the Right to Property: Conflicts Between Public Welfare and Private Interests, the Brazilian Approach", Law \& Business Review of the Americas, Vol. 20, Summer 2014, p. 484.

Emily M. Cowleya, "The Right to Health: Guatemala's Conflicting Obligations Under The Central American Free Trade Agreement and The International Covenant On Economic, Social, and Cultural Rights", Michigan State University Journal of Medicine \& Law, Vol. 11, 2007, p. 231. license and the protection of the right to health.

In addition, the implementation of compulsory license in developing countries sometimes causes protest from developed countries since the compulsory license may jeopardize the interest of the patent holder of the essential medicines in developed countries. However, the developing countries have to find practical reasons to implement compulsory license in order not to contradict the requirements of the TRIPs Agreement. One of the efforts to be performed by the developing countries is to adopt national policy regulations to implement compulsory license, such us to define what national emergency situation, non-commercial used and the mechanism of the compulsory license in the national law.

The problems of this article are: first. is the compulsory license of pharmaceutical product in the TRIPs Agreement in accordance with the right to health in international human right law?; second, what is the legal implication of compulsory license regarding pharmaceutical product in the TRIPs Agreement to the protection of the right to health in developing countries?. Thus, the aim of the research is to analyse comprehensively the legal implication of compulsory license pharmaceutical product in the TRIPs Agreement to the protection of the right to health in developing countries.

\section{Research Methods}

This library research belongs to normative research which uses secondary data consisting of primary legal material, secondary legal material and tertiary legal material. Then, the approaches employed in the research are conceptual approach and comparative approach. The conceptual approach is used to understand the concept of compulsory license and the relationship with the concept of the right to health, while comparative approach is employed to examine the implementation of compulsory license in some developing countries, such as, Indonesia, Malaysia, Brazil, India and South Africa. All the collected materials are grouped 
based on each variable and qualitatively analyzed and descriptively presented.

\section{Discussion}

Compulsory License of Pharmaucitical Product in the TRIPs Agreement based on International Human Rights Law Perspective

The TRIPs Agreement does not explicitly mention the term compulsory license in the text but Article 31 is understood to allow compulsory license and government use without authorization of the right holder. ${ }^{7}$ Article 31 of the TRIPs Agreement states: "Where the law of a Member allows for other use of the subject matter of a patent without the authorization of the right holder, including use by the government or third parties authorized by the government, there are some following provisions shall be respected", such as, Article 31 (a), (b), (f) and $(\mathrm{j})$ :

(a) authorization of such use shall be considered on its individual merits;

(b) such use may only be permitted if, prior to such use, the proposed user has made efforts to obtain authorization from the right holder on reasonable commercial terms and conditions and that such efforts have not been successful within a reasonable period of time. This requirement may be waived by a Member in the case of a national emergency or other circumstances of extreme urgency or in cases of public noncommercial use. In situations of national emergency or other circumstances of extreme urgency, the right holder shall, nevertheless, be notified as soon as reasonably practicable.In the case of public non-commercial use, where the government or contractor, without making a patent search, knows or has demonstrable grounds to know that a valid patent is or will be used by or for the government, the right holder shall be informed promptly;

Timothy Bazzle, "Pharmacy of the Developing World: Reconciling Intellectual Property Rights in India with The Right To Health: Trips, India's Patent System and Essential Medicines", Georgetown Journal of International Law, Vol. 42, 2011, p. 788 (f) any such use shall be authorized predominantly for the supply of the domestic market;

(j) any decision relating to the remuneration provided in respect of such use shall be subject to judicial review or other independent review by a distinct higher authority in that Member;

Article 31 does not hamper the grounds on which compulsory licensing is allowable, and it become the authority of states to determine the balance of the protection of patent holders and the interest of the patients. Article 31(b) provides that this limitation may be waived by a Member in the event of a national emergency. Unfortunately, there is no explanation what constitute national emergency in the TRIPs Agreement. The Contracting Parties of the TRIPs Agreement have a freedom to define what national emergency is. For example, the endemic of HIV/AIDs which occur in a developing country can be considered as national emergency. Article 6 of the International Health Regulations (2005) (IHR) imposes an obligation on countries to notify WHO, via the National IHR Focal Point, of "all events which may constitute a public health emergency of international concern within its territory".1The IHR define a "public health emergency of international concern" as an extraordinary event that is determined to "constitute a public health risk to other States through the inter-national spread of disease and to potentially require a coordinated international response". World Health Organization (WHO) Chapter 11: Public health Emergencies Summary Points. ${ }^{8}$ Thus, there is no uniform definition of the national emergency. The definition of national emergency is based on the national policy and interest of each state.

One of the most important restrictions is adopted in Article 31(f) - the use of commercial license should be "predominantly for the supply of the domestic market." The term "predominantly" in Article 31(f) implies that some ex-

8 WHO, without years, Health Law, retrieved on: http:// www.who.int/healthsystems/topics/healthlaw/chapter11.pdf Accessed on January10 th 2018. 
portation under compulsory license from the exporting nation could not be allowed to be exported to other countries which do not have the capacity to produce the medicine. Based on Article 31 (f) It is clear that initiates a problem in the implementation of compulsory license in developing countries which do not have the capability to produce medicine.

There are many developing countries which do not have the capacity to produce the essential medicine, thus, it is necessary to find a solution to solve the problem. Consequently, the fourth WTO Ministerial Conference, held in November 2001 in Doha, Qatar, adopted a Declaration on TRIPS and Public Health (hereinafter Doha Declaration) which affirmed the sovereign right of governments to take measures to protect public health. ${ }^{9}$ Based on the Doha Declaration, the Member of the TRIPs Agreement has a freedom to implement and to interpret the Provision of the TRIPs Agreement to support the public health.

Article 5 (c) Doha Declaration recognizes the flexibility of the TRIPs Agreement provides a freedom to state to determine what kind of legal basis to grant compulsory license and to determine the national emergency which are various from one state to another state to protect public health. ${ }^{10}$ Thus, Article 5 of the Doha Declaration has to be read in the light of article 6 of the Doha Declaration which gives opportunity to states to carry out parallel import. ${ }^{11}$ This term refers to "a practice in which a third party imports a product marketed in a foreign country by the patent holder, in competition with the product that same patent holder imports or manufactures locally". ${ }^{12}$

$9 \quad$ Holger Hestermeyer, "Human Rights and the WTO: The Case of Patents and Access to Medicines", International Trade Law \& Regulation, Vol. 14 No. 6, 2008, p. 126.

10 Mohammad Towhidul Islam, "TRIPs Agreement and Public Health: Implications and Challenges for Bangladesh", International Trade Law \& Regulation, Vol. 17 No. 1,2011 , p. 22

11 Samira Guennif and Julien Chaisse, "Present Stakes Around Patent Political Economy: Legal and Economic Lessons from the Pharmaceutical Patent Rights in India", Asian Journal of WTO \& International Health Law \& Policy, Vol. 2 No. 1, March, 2007, p. 75.

12 Charles T. Collins-Chase, "The Case Against Trips-Plus Protection in Developing Countries Facing Aids Epide-
On August 30, 2003, the WTO General Council for TRIPs resolved the dispute on implementing the Doha Declaration by adopting a decision which essentially permitted a patent exception rule to allow countries to produce medicine for export to fulfill public health needs in countries that do not have production capacities. ${ }^{13}$ Finally, in order, the decision has a legal obligation to the Member States of WTO, on 6 December 2005, the WTO issued a Protocol to amend Article 31(f) become Article 31 (f) bis of the TRIPs Agreement which allows parallel import. ${ }^{14}$

\section{The Righ to Health in the International Hu- man Right Law}

Article 25(1) of the UDHR affirms that "everyone has the right to a standard of living adequate for the health of himself and of his family, including food, clothing, housing and medical care and necessary social services." 15 Hence, based on Article 25 (1) UDHR, a state has obligation to achieve the standard stipulated on the Article. Besides, there are some International instruments, which regulate the rich to health, such as Article 12 (1) of the International Covenant on Economic, Social, and Cultural Rights (hereinafter ICESCR). ${ }^{16}$ Article 5(e) (iv) of the International Convention on the Elimination of All Forms of Racial Discrimination of 1965, and Articles 11 (1) (f) and 12 of the Convention on the Elimination of All Forms

mics", University of Pennsylvania Journal of International Law, Vol. 29, Spring 2008, p. 768.

13 Sartika Nanda Lestari, "Implementasi Compulsory Licensing Terhadap Obat-Obatan Dalam Bidang Farmasi di Indonesia (Studi Berdasarkan Doha Declaration on The TRIPs Agreement and Public Health)", Thesis Program Magister Ilmu Hukum Fakultas Hukum Universitas Diponegoro, Semarang 2012. p. 77, retrieved from the website: http://eprints.undip.ac.id/42149/1/Bab_I-II.pdf, aaccessed on November 4, 2017.

14 World Trade Organization, without Years, Amendment of the TRIPS Agreement', WT/L/641, 8 December 2005 Amendment, retrieved on website: https://www.wto. org/english/tratop_e/trips_e/wtl641_e.htm, accessed on November 4, 2017.

15 Tina S. Bhatt, "Amending Trips: A New Hope For Increased Access to Essential Medicines", Brooklyn Journal of International Law, Vol. 33, 2008, p. 600.

16 Kojo Yelpaalaa, "Quo Vadis WTO? The Threat of Trips and the Biodiversity Convention to Human Health and Food Security", Boston University International Law Journal, Vol. 30, 2012, p. 65-66. 
of Discrimination against Women (hereinafter CEDAW) of $1979 .{ }^{17}$

Access to medicine affects the right to health. The fundamental legal basis the right to health is stipulated in the article 12 (1) of ICESCR, which recognizes "the right of everyone to the enjoyment of the highest attainable standard of physical and mental health." Consequently it needs the active effort of a state to materialize it, which includes the prevention, treatment and control of epidemic, endemic, occupational and other diseases and the creation of conditions which would assure to all medical service and medical attention in the event of sickness. ${ }^{18}$

Related to the health policy in Indonesia, as one of the examples of developing countries, health is one of the eleven priorities in the national development program. It is stipulated in the Regulation of the President of the Republic of Indonesia Number 5 of 2010 on the National Medium -Term Development Plant (RPJMN) 2010-2015. Furthermore, the right to health is also recognized as human right based on Act Number 36 Year 2009 regarding Health. Article 5 (1) Act number 36 Year 2009 states: "Every people shall have equal right in obtaining access to health resources". Thus, it becomes the obligation of the government of Indonesia how to fulfill the right of the people. It has been stipulated in Article 16 Act Number 36 Year 2009: "The Government shall be responsible for the availability of fair and proportional distributed resources of health ${ }^{19}$ for all people in order to achieve maximum health degree. Thus, it can be submitted that the health policy of Indonesia is in accordance to the General

17 Timothy Bazzle, loc.cit.

18 Adam Houstona, "A Scientific Approach to Intellectual Property and Health: Innovation, Access, and a Forgotten Corner of the Universal Declaration of Human Rights", John Marshall Review of Intellectual Property Law, Vol. 13, 2014, p. 800-801.

19 Article 1 (2) Act, Number 36 Year 2009, it states: "Resources of health refers to any kind of fund, power, health supply, pharmacy supply and health equipments as well as health service facilities and technology used to maintain health efforts made by the Government, local government, and/or the people".
Comment No 14 of the Highest Commissioner of Human Rights. ${ }^{20}$

In its General Comment No. 14 on the "Right to the Highest Attainable Standard of Health," the Economic, Social and Cultural Rights Committee (hereinafter ESCR Committee") explained that all health care facilities, goods, and services including medications and the provision thereof should be: (1) available in sufficient quantity; (2) accessible to everyone without discrimination; (3) acceptable in the sense of respectful of medical ethics and customs; and (4) of good quality and scientifically appropriate. ${ }^{21}$ Thus, it is essential to materialize those accessibility of the right to health by providing easy access and affordable essential medicine which is demanded by the patients.

Conflict or Congruence between Compulsory License of pharmaceutical Product in the TRIPs Agreement and the Protection of the Right to Heath in Developing Countries

TRIPs Agreements are auspicious steps toward making access to HIV/AIDS medicine becomes a reality for developing nations. ${ }^{22}$ The WTO negotiations and agreements outstandingly avoid any obvious recognition of human rights, particularly the right to health. The TRIPs Agreement more focus on public health rather than the discussion to the protection of individual human rights, such as the right to health. ${ }^{23}$ Consequently, it results in less effec-

20 Office of the Highest Commissioner of Human Rights, CESCR General Comment No. 14: The Right to the Highest Attainable Standard of Health (Art. 12). Adopted at the Twenty-second Session of the Committee on Economic, Social and Cultural Rights, on 11 August 2000 (Contained in Document E/C.12/2000/4), retrieved on: http://www.refworld.org/pdfid/4538838d0.pdf, Accessed on November 4, 2017.

21. Rudolf V. Van Puymbroeck, "Basic Survival Needs And Access To Medicines-Coming To Grips With TRIPs: Conversion + Calculation", Journal of Law, Medicine \& Ethics, Vol. 38, Fall 2000, p. 521-522.

22 Erika Georgea," The Human Right to Health and HIV/ AIDs: South Africa and South-South Cooperation to Reframe Global Intellectual Property Principles and Promote Access to Essential Medicines", Indiana Journal of Global Legal Studies, Vol. 18, winter 2012, p. 179-180.

23 Chuan-Feng Wu "Raising the Right to Health Concerns Within the Framework of International Intellectual Property Law", Asian Journal of WTO \& International Health Law \& Policy, Vol. 5, 2010, p. 144-145. 
tive laws to achieve access to HIV/AIDS medicines.

The majority of TRIPs Agreement Members are also the Members of ICESCR, thus, there is possibility of conflict between the obligations in the TRIPs Agreement and the obligation in the ICESCR. At glance, the two agreements regulate two different things; the TRIPs Agreement regulates intellectual property right while ICESCR regulates the protection of human right. Actually, the two Agreements interrelate since the access of medicine affects the protection to the right to health. The TRIPs Agreement should be flexibly interpreted to promote access to medicine. ${ }^{24}$ The Doha Declaration opens the way for developing countries to access essential medicine.

The Legal Implication of Compulsory License of pharmaceutical Products in the TRIPs Agreement to the Protection of the Right to Heath in Developing Countries

Compulsory license which has been regulated based on the TRIPs Agreement and also Doha Declaration causes some legal implications in developing countries to access to medicine in order to protect the right to health. First, one of the legal implication is the accessibility and affordability of the essential medicine which are deserved by patients in developing countries, such as Antiviral and Antiretroviral, ${ }^{25}$ since the developing countries can use the justification based on the reason of protecting public health and also the developing countries have a freedom to issue the law to determine what emergency situation to justify to implement compulsory license. Thus, the compulsory license enables state to protect the right to health

Second, the developing countries can exercise the compulsory license to support the right to health. However, it is necessary to adopt policy and regulations to take the benefit of the compulsory license to protect the right to health. Indeed, the right to health does not only oblige states to take positive measures to

24 Chuan-Feng Wu, op.cit, p. 81-82.

25 Adam Houstona, op.cit, p. 802 ensure the access to affordable medicine for all, but also requires them to refrain from taking measures that could impede this access. Consequently, when implementing compulsory license rules, countries have to take the right to health into account, ensuring the access to quality medicines is affordable prices, ${ }^{26}$ so that the patients in developing countries will not find difficulty in accessing the medicine.

Third, access to essential medicine which is protected by patent has already become the important issue in international human rights law. The accessibility and affordability of essential medicine needs to be materialized in order to protect the right to health. ${ }^{27}$ It has been noted by the UN Sub-Commission on Human Rights ${ }^{28}$ that there are apparent conflicts between the fundamental principles of international human rights and the principles of international intellectual property regime as embodied in the TRIPS Agreement. Thus, the compulsory license can be used as a legal instrument to justify of producing generic version of essential medicines in developing countries. Hence, the TRIPs Council made an Amendment of the TRIPs Agreement in November 2005 which permits the parallel import.

Finally, international human rights documents cannot serve as a substitute for an explicit recognition of the right to medicine in the TRIPS Agreement. By embodying the right in the TRIPS Agreement, the WTO would help secure the right to medicine by supplying Member

26 Center for Health, "Transnational Pharmaceutical Corporations' Legal and Moral Human Rights Responsibilities in Relation to Access to Medicines", "Health and Human Rights Resource Guide". retrieved from: https: / /www.hhrguide.org/2017/06/09/access-tomedicines-and-human-rights/. Accessed on November 4, 2017.

27 Peter K. Yua, “Intellectual Property in International Perspective: Institute for Intellectual Property \& Information Law Symposium", Houston Law Review, Vol.46, 2009, p. 990.

28 WTO Doha Ministerial Declaration on the TRIPS Agreement and Public Health, WT/MIN(01)/DEC/2 (14 Nov. 2001) [hereinafter Declaration on TRIPS and Public Health]; WTO Council for TRIPS, Implementation of $\mathrm{Pa}$ ragraph 6 of the Doha Declaration on the TRIPS Agreement and Public Health, IP/C/W/405 (30 Aug. 2003) [hereinafter WTO, Implementation of Paragraph 6]". Available on the website: https://www.wto.org/english/res_e/booksp_e/ddec_e.pdf, retrieved on June 7, 2017. 
States with a legal justification for implementing patent laws that do not impede access to essential medicines. Hence, the compulsory license is the gate way to embody protection of the right to health in developing countries, if the developing countries can performed the legal instrument which is in accordance with the TRIPs Agreement.

\section{Legal Implication of Compulsory License by State Practicses to Protect the Right to Health in Some Developing Countries}

The right to health has been recognized as part of human right and as constitutional right in most developing countries. On the other hand, as the Members of the TRIPs Agreement in the WTO, states have obligation to harmonize the national intellectual property right law in accordance with the TRIPs Agreement. In order to analyse further the legal implication of compulsory license to the protection of the right to health in developing countries, the research analyses briefly the legal implication of compulsory license in five developing countries, namely Indonesia, Malaysia, Brazil, South Africa and India.

First, the legal implication of compulsory license of pharmaceutical products in indonesia in order to protect the right to health. The right to health in Indonesia is not explicitly stipulated in the Indonesian Constitution and Act Number 36 Year 2009 on Health. The right to health can be found in Article $28 \mathrm{H}$ (1) Indonesian Constitution, and Article 62 Human Right Act which regulates the right to have health service. However, when the Indonesian government would like to protect the right to health in Indonesia, they have to comply with the TRIPs Agreement. Hence, the Indonesian government have already amended the Patent Act in accordance with the TRIPs Agreement. The reason of exercising compulsory license in Indonesia is based on Article 109 Indonesian Patent Act. However, unlike Malaysia which imported generic versions of the drugs from India, Indonesia used the compulsory license to appoint local manufacturers to produce 7 medicines for treating Hepatitis B and HIV/AIDs based on
Decree of the President Republic of Indonesia No 76 of $2012 .{ }^{29}$

Second, the legal implication of Compulsory License of Pharmaceutical Products in Malaysia in order to protect the Right to Health. The right to health in Malaysia is recognized as a human right and also as Constitutional right in the Federal Constitution. ${ }^{30}$ The Malaysian government seriously concerns and protects the right to health. Thus, when there is an epidemic case of HIV/AIDS in Malaysia which can be considered as national emergency, the government of Malaysia issued compulsory license for the medicine to secure the patients because the price of the medicine is very expensive. Malaysia was the first Asian country that harmonized its legislation ${ }^{31}$ with the Doha Declaration and the 2003 Decision.

Based on the compulsory license regulated in the TRIPs Agreement, Malaysia can take advantages of the mechanism. Under Section 84 of the Malaysian Patents Act, it allows the grant of compulsory licence in case of national emergency or in public interest. Based on this provision, Malaysia issued the license to import generic Antiretroviral (ARV) medicines from India, and this measure has certainly helped the country bring down the cost of treatment. ${ }^{32}$

Third, the legal implication of Compulsory License of Pharmaceutical Products in Brazil in order to protect the Right to Health. The Brazilian Constitution of 1988 granted the right to health to all citizens and mandated the creation of a national health-care system. Thus, when there is an epidemic case of HIV/AIDS in Brazil which can be considered as national emergency, the government of Brazil issued compulsory license for the medicine to secure

\footnotetext{
29 Helmi Khair, "Is The Right to Health Undermined by The Agreement of Trade-Related Aspects of Intellectual Property Rights? Journal of Academia UiTM Negeri Sembilan, Vol. 4, 2016, p. 30

30 Ibid.

31 Raadhika Gupta, “Compulsory Lisencing under TRIPs: How Far it Addresses Public Health Concern in Developing Nations, Journal of Intellectual Property Rights, Vol. 15, September 2010, p. 362.

32 Samira Guennif and Julien Chaisse, op.cit, p. 79-80.
} 
the patients, ${ }^{33}$ because the price of the medicine is costly. However, it should bear in mind that Brazil is the member of the TRIPs Agreement; consequently, Brazil has to comply with the TRIPs Agreement in exercising the compulsory license. Based on Article 31 (b) TRIPs Agreement, Brazil has consistently taken a position in favor of public health in trying to negotiate a balance between pharmaceutical IPR and access to medicine. ${ }^{34}$

Fourth, the legal implication of compulsory license of pharmaceutical products in South Africa in order to protect the Right to Health. South Africa is estimated to have the highest absolute number of people living with HIV of any country in the world, it is also home to the world's largest public sector antiretroviral (ARV) treatment programme. ${ }^{35}$ Access to medicines is an essential component of the right to health. Undoubtedly, the challenge ahead is to ensure that the South African government is equipped with a public health-sensitive legal framework that can achieve the price reductions needed to sustain a public HIV treatment programme and ensure all people's access to medicines. ${ }^{36}$ Indeed, South Africa as the member of the TRIPs Agreement, its Patent Act has to comply with the TRIPs Agreement.

Unfortunately, Africa does not take advantage of the compulsory license which is adopted in Article 31 TRIPs Agreement since South Africa feared retaliation from other countries $^{37}$ especially United States. Thus, what has been done by the South African government only make bilateral agreement with United State to get reducing price of the essential medicine, especially in a national emergency situation dealing with epidemic HIV/AIDS and its

33 Anna Dontje," Rethinking Trips: The Future of Pharmaceutical Patents", Wisconsin International Law Journal, Vol. 33, Fall, 2015, p. 388.

34 Ibid.

35 Erika George, "The Human Right to Health And HIV/ AIDs: South Africa and South-South Cooperation to Reframe Global Intellectual Property Principles and Promote Access to Essential Medicines", Indiana Journal of Global Legal Studies, Vol. 38, Winter, 2011, p. 168.

36 Ibid.

37 Siobhán Elizabeth Stade Murillo, Fair Or Fraud: Has The Protocol Amending Trips Flourished Or Failed?", Indiana International \& Comparative Law Review, Vol. 27, 2017. P. 198 citizens does not have capability to afford the medicine.

Fifth, the legal implication of compulsory license of pharmaceutical products in India in order to protect the Right to Health. The Constitution of India has provisions regarding the right to health. The Constitution incorporates provisions guaranteeing everyone's right to the highest attainable standard of physical and mental health. ${ }^{38}$ In Indian Constitution does not explicitly recognize the fundamental right to health. However, Article 21 of the Constitution of India guarantees a fundamental right to life and personal liberty.

The Indian Patent Act of 1970 prohibited the patent ability of pharmaceutical products in order to boast the availability of low-cost medicines. However, the Act allowed patents on the manufacturing process of said products. As a result of the Act India turn out to be the largest manufacturer and provider of generic pharmaceutical products in the world. However, when India becomes the member of the TRIPs Agreement, India has to comply with the TRIPs Agreement. The TRIPS Agreement, although attempting to establish uniformity of international patent law, allowed each individual country to establish its standards of patent ability as long as the standards did not violate the agreement.

Accordingly, Article 31 of the TRIPS Agreement, without stating the words "compulsory license," establishes a procedure by which a compulsory license could be granted if certain conditions were met. The Patent Act of 1970 was amended in 2005. The legal implication of the Compulsory license causes the Indian Patent Act has to be harmonized with the TRIPs Agreement. ${ }^{39}$

Thus, it is reasonable that the implementation of compulsory license for essential medi-

38 Indrajit Khandekar et al, "Right to Health Care", Journal Indian Acad Forensic Med, Vol. 34 No. 2. April-June 2012, p. 160.

39 Javier Esparza, “Indian Patent Law: Working Within the TRIPs Agreement Flexibilities to Provide Pharmaceutical Patent Protection While Protecting Public Health", retrieved from: http://heinonline.org/HOL/Landing Page?handle=hein. journals/jtrnlwp24\&div=8\&id=\&page =. Accessed on 19 December 2017. 
cine in order to protect, to fulfill and to promote the right to health. Provisions related to the grant of compulsory license in India are prescribed under Sections 82-94 (Chapter XVI) of the Patents Act, 1970, and Rules 96-102 (Chapter XIII) of the Patents Rules, 2003. ${ }^{40}$ However, in issuing Compulsory license India also refers to the International TRIPs Agreement Article 31 and its Amendment and Doha Declaration. The Compulsory license is issued in the circumstances of national emergency or in circumstances of extreme urgency or in case of public non-commercial use including public health crises.

\section{Conclusion}

The compulsory license of pharmaceutical product in the TRIPs Agreement is in accordance with the protection of the right to health in international human right law. It can be proven from the efforts that have been done by WTO to harmonize the protection of patent holders and the protection of the right to health by providing compulsory license mechanism in the TRIPs Agreement and the Doha Declaration as well as the amendment of of TRIPs Agreement in November 2005. In the mean time, the international instruments of human rights, such as UDHR and ICESCR established the protection of the right to health for all people. However, the developing countries as the member of the TRIPs Agreement, they have their own policy and national regulations to regulate the implementation of the compulsory license. The developing countries utilize the compulsory license scheme to protect the right to health.

The legal implication of compulsory license regarding pharmaceutical products in the TRIPs Agreement to the protection of the right to health in developing countries has caused accessibility and affordability of essential medicine to secure deadly disease, such as HIV/ AIDs in developing countries. Indonesia, Malay-

40 Vipin Mathur et.al, "Compulsory Licensing of Pharmaceutical Patents In India: A Research Study", "European Journal of Pharmaceutical and Medical Research, Vol. 3, 2016, p. 537. sia, Brazil, South Africa and India recognize the right to health in their Constitution. Hence, in order to protect, to fulfill and to promote the right to health for their citizens, they issued compulsory licence. The Doha Declaration clarifies the right of WTO Members to incorporate flexibility built into the TRIPS Agreement into their domestic intellectual property laws to protect and promote the right to health. Therefore, the direct legal implication of exercising compulsory license in developing countries has already enabled the developing countries to establish the policy and national regulations how to regulate compulsory license in the national level and also to utilize the compulsory license to protect the right to health.

\section{Suggestion}

The legal implication of the Compulsory license of pharmaceutical products in developing countries to the protection of the right to health in developing countries are not so different among the developing countries. However, since there are different situation and condition of each developing country, specific policy of each developing country to deal with the deadly disease, such as HIV/AIDs from one country to another country is required. Thus, the following suggestions are proposed: firstly, each developing country has to regulate the compulsory license in its national law especially when determining the national emergency, parallel import and non commercial use of the essential medicine; secondly, in order to prevent disputes among developing countries and the pharmaceutical industries in developed countries, the government involvement in developed countries is needed to encourage the pharmaceutical industries to participate in the protection of the right to health.

\section{References}

Andemariam, Senai W. "The Cleft-Stick Between Anti-Retroviral Drug Patents and HIV/AIDS Victims: An In-Depth Analysis of the WTO's Trips Article 31 Bis Amendment Proposal of 6 December 2005', In- 
tellectual Property Quarterly, Vol. 4, 2007. Pp. 414-470;

Bazzle, Timothy. "Pharmacy of the Developing World: Reconciling Intellectual Property Rights in India with The Right to Health: Trips. India's Patent System and Essential Medicines". Georgetown Journal of International Law. Vol. 42. 2011. Pp. 785822;

Bhatt, Tina S, Amending Trips: A New Hope For Increased Access to Essential Medicines", Brooklyn Journal of International Law, Vol. 33, 2008. Pp. 597-438;

Center for Health and Human Right. without years. Health and Human Rights Resource Guide. Retrieved from: https://www. hhrguide.org/2017/06/09/access-tomedicines-and-human-rights/. Accessed on November $4^{\text {th }} 2017$;

Chase, Charles T Collins. "The Case Against Trips-Plus Protection in Developing Countries Facing Aids Epidemics". University of Pennsylvania Journal of International Law. Vol. 29. Spring 2008. Pp. 763-807;

Cowleya, Emily M. "The Right to Health: Guatemala's Conflicting Obligations Under The Central American Free Trade Agreement and The International Covenant On Economic, Social, and Cultural Rights". Michigan State University Journal of Medicine \& Law. Vol. 11 Issue 1. 2007. Pp. 227-259;

Dontje Anna," Rethinking Trips: The Future of Pharmaceutical Patents", Wisconsin International Law Journal, Vol. 33, Fall, 2015. Pp. 380-417;

George, Erika. "The Human Right to Health and HIV/AIDs: South Africa and South-South Cooperation to Reframe Global Intellectual Property Principles and Promote Access to Essential Medicines". Indiana Journal of Global Legal Studies. Vol. 38. Winter. 2011.Pp. 167-205;

Esparza, Javier. “Indian Patent Law: Working Within the TRIPs Agreement Flexibilities to Provide Pharmaceutical Patent Protection While Protecting Public Health". Available on website: http://heinonline. org/HOL/LandingPage?handle=hein.journ als/jtrnlwp24\&div=8\&id=\&page=. retrieved on December 19, 2017;

Guennif, Samira and Chaisse Julien. "Present Stakes Around Patent Political Economy: Legal and Economic Lessons from the
Pharmaceutical Patent Rights in India". Asian Journal of WTO \& International Health Law \& Policy. Vol. 2 No. 1. March. 2007. Pp. 65-102;

Gupta, Raadhika. “ Compulsory Lisencing under TRIPs: How Far it Addresses Public Health Concern in deverloping Nations. Journal of Intellectual Property Rights. Vol. 15. September 2010. Pp. 357-363;

Houstona, Adam, "A Scientific Approach to Intellectual Property and Health: Innovation. Access. and a Forgotten Corner of the Universal Declaration of Human Rights". John Marshall Review of Intellectual Property Law. 2014. Vol 13. No.794. Pp. 794-827;

Hestermeyer, Holger. "Human Rights and the WTO: The Case of Patents and Access to Medicines". International Trade Law \& Regulation. Vol 14. No.6. 2008. Pp 122136;

Khandekar, Indrajit. et al. "Right to Health Care". Journal Indian Acad Forensic Med. Vol. 34. No. 2 April-June 2012. Pp. 160164;

Khair, Helmi. "Is The Right to Health Undermined by The Agreement of Trade-Related Aspects Of Intellectual Property Rights?. Journal of Academia UiTM Negeri Sembilan. Vol. 4. 2016. Pp. 28-33;

Martinsa, Lilian. "The Right to Health Versus the Right to Property: Conflicts Between Public Welfare and Private Interests. the Brazilian Approach". Law \& Business Review of the Americas. Vol. 20. Summer. 2014. Pp. 341-402;

Mathur, Vipin et.al. "Compulsory Licensing of Pharmaceutical Patents in India: A Research Study". "European Journal of Pharmaceutical and Medical Research. Vol. 3. 2016. Pp. 532-543;

Lestari, Sartika Nanda. "Implementasi Compulsory Licensing terhadap Obat-Obatan dalam Bidang Farmasi di Indonesia (Studi Berdasarkan Doha Declaration on The TRIPs Agreement and Public Health)". Thesis. Program Magister Ilmu Hukum Fakultas Hukum Universitas Diponegoro. Semarang 2012. Retrieved from the website: http://eprints.undip.ac.id/42149/1/Bab_ I-II.pdf. Accessed on November $4^{\text {th }}$ 2017;

Siobhán, Elizabeth Stade Murillo. "Fair or Fraud: Has The Protocol Amending Trips Flourished or Failed?". Indiana Interna- 
tional \& Comparative Law Review. Vol. 27. 2017. Pp. 191-215;

Islam, Mohammad Towhidul. "TRIPs Agreement and public health: implications and challenges for Bangladesh". International Trade Law and Regulation. Vol. 17. No.1. 2011. Pp 10-67;

Van Puymbroeck, Rudolf V. "Basic Survival Needs And Access To Medicines - Coming To Grips With TRIPs: Conversion + Calculation". Journal of Law. Medicine \& Ethics. Vol. 38. Fall 2000. Pp. 520-594.

World Health Organization (WHO). Without years. Chapter 11: Public health Emergencies Summary Points. Retieved from the website: http://www. who.int/health systems/topics/health-law/chapter11.

pdf. Accessed on November 10 January, 2018.

World Trade Organisation, without years. Amendment of the TRIPS Agreement', WT/L/641, 8 December 2005 Amendment. retrieved from website: https:// www.wto.org/english/tratop_e/trips_e/ wtl641_e.htm. Accessed on November 4, 2017.

- 14 Nov 2001. Doha Ministerial Declaration on the TRIPS Agreement and Public Health. Retrieved from: https:// www.wto.org/english/thewto_e/minist_ e/min01_e/mindecl_trips_e.htm.

Accessed on June 7, 2017.

Wu, Chuan-Feng. "Raising the Right to Health Concerns Within the Framework of International Intellectual Property Law". Asian Journal of WTO \& International Health Law \& Policy. Vol. 5. 2010. Pp. 141-209.

"Transnational Pharmaceutical Corporations' Legal and Moral Human Rights Responsibilities in Relation to Access to Medicines". Asian Journal of WTO \& International Health Law \& Policy. Vol. 7 No. 1. March 2012. Pp. 77-142;

Yelpaalaa, Kojo. "Quo Vadis Wto? The Threat Of Trips And The Biodiversity Convention to Human Health and Food Security". Boston University International Law Journal. Vol. 30. 2012.Pp. 55-131;

Yua, Peter K. "Intellectual Property in International Perspective: Institute for Intellectual Property and Information Law Symposium". Houston Law Review. Vol. 46. 2009. Pp. 979-1059. 